\title{
Comparative study of microfibrillar collagen hemostat (Colgel) and oxidized cellulose (Surgicel) in high transfusion-risk cardiac surgery
}

Mustafa Sirlak, MD

Sadik Eryilmaz, MD

Levent Yazicioglu, MD

Ugursay Kiziltepe, MD

Zeynep Eyileten, MD

Mustafa Serkan Durdu, MD

Refik Tasoz, MD

Neyyir Tuncay Eren, MD

Atilla Aral, MD

Bulent Kaya, MD

Hakki Akalin, MD
From the Cardiovascular Surgery Department, Ankara University Medical School, Ankara, Turkey.

Received for publication Feb 4, 2002; revisions requested June 13, 2002; revisions received July 21, 2002; accepted for publication Aug 16, 2002.

Address for reprints: Mustafa Sirlak, MD, Cardiovascular Surgery Department, Ankara University Medical School, Yesilyurt mah. Yesilyurt sok. 49/1 A.Ayranc1, Ankara, Turkey (E-mail: drsirlak@ hotmail. com).

J Thorac Cardiovasc Surg 2003;126:666-70

Copyright () 2003 by The American Association for Thoracic Surgery

$0022-5223 / 2003 \$ 30.00+0$

doi:10.1016/S0022-5223(03)00042-4
Objective: The effects of microfibrillar collagen hemostat (Colgel) and oxidized cellulose (Surgicel) on bleeding and allogeneic transfusions were compared in cardiac operations with a predicted high risk of bleeding.

Methods: Between August 1999 and November 2001, 71 patients undergoing elective, high risk of bleeding operations were studied after giving informed consent. The procedures included repeat cardiac operations (aorta-coronary bypass operations or valvular operations), ascending aortic aneurysm repair necessitating deep hypothermic circulatory arrest, and ascending aortic grafting without deep hypothermic circulatory arrest. Subjects were excluded if they had recent ( $<5$ days) acetylsalicylic acid ingestion, thrombolytic therapy, or anticoagulant therapy (heparin $<4$ hours preoperatively or warfarin $<3$ days preoperatively). Consenting subjects were randomized to receive either Colgel or Surgicel.

Results: Chest tube drainage in the first 24 hours was $373 \pm 143 \mathrm{~mL}$ in the Colgel group and $571 \pm 144 \mathrm{~mL}$ in the Surgicel group $(P=.01)$. Total postoperative chest tube drainage was $423 \pm 154 \mathrm{~mL}$ (range, $280-1100 \mathrm{~mL}$ ) in the Colgel group and 677 $\pm 128 \mathrm{~mL}$ (range, $285-1350 \mathrm{~mL}$ ) in the Surgicel group $(P=.01)$. In addition, chest tube drainage was compared between the 2 groups every 3 hours after operation. Blood loss in the first 3 postoperative hours was significantly less in the Colgel group (132 \pm 41 vs $228 \pm 57 \mathrm{~mL}, P<.001)$. In the following 3-hour interval, this significant difference persisted $(67 \pm 24$ vs $121 \pm 49 \mathrm{~mL}, P<.001)$.

Conclusions: In conclusion, the easy application, low cost, and significant blood-loss reduction effect of microfibrillar collagen powder renders this agent attractive for cardiac operations associated with high risk of bleeding.

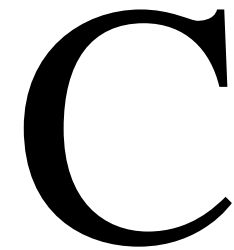
ardiovascular surgery is associated with a significant consumption of allogeneic blood products, often as a result of acquired hemostatic defects and/or incomplete surgical hemostasis. Management of the abnormal bleeding exposes the patient to the morbidity of reoperation and/or excessive, and sometimes inappropriate, bloodproduct transfusions. However, some patients or operations are at an increased risk for allogeneic transfusions because of excessive bleeding perioperatively. The risk factors include repeat cardiac operation; complex procedures, such as multiple valve replacements or aortic arch repairs; and procedures requiring 
long cardiopulmonary bypass (CPB) times, such as combined procedures (valve replacement plus myocardial revascularization). ${ }^{1}$ For aortic operations necessitating deep hypothermic circulatory arrest (DHCA), hypothermia accounts for the dysfunction of the normal coagulation mechanisms. $^{2}$

Pharmacologic agents to reduce bleeding have gained much interest recently because they are readily available, easy to administer, can be used prophylactically, do not require the use of costly equipment, and appear to be very safe and efficacious. The perioperative use of tranexamic acid, $\epsilon$-aminocaproic acid, and aprotinin have gained acceptance around the world for the prophylactic reduction of allogeneic blood transfusions in cardiac operation patients. ${ }^{1}$ Various surgical tissue adhesives have been investigated to control bleeding from suture lines and needle holes in synthetic grafts to native aortic tissues. ${ }^{2}$ In the effort to reduce postoperative bleeding, antifibrinolytic agents have also been applied topically into the pericardial cavity.,4 Also, a significant reduction in chest tube drainage after cardiac operations was noted when the anterior mediastinal structures were sprayed with fibrin glue prior to sternal closure. ${ }^{5}$ In this comparative randomized trial, we compared the efficacy of microfibrillar collagen hemostat (Colgel) and Surgicel in cardiac operations with a predicted high risk of bleeding.

\section{Patients and Methods}

Between August 1999 and November 2001, 71 patients undergoing elective, high risk of bleeding operations were studied after giving informed consent. The procedures included repeat cardiac operations (aorta-coronary bypass [ACB] or valvular operations), ascending aortic aneurysm repair necessitating DHCA, and ascending aortic grafting without DHCA. Subjects were excluded if they had recent ( $<5$ days) acetylsalicylic acid ingestion, thrombolytic therapy (streptokinase, urokinase, or tissue plasminogen activator $<1$ day), or anticoagulant therapy (heparin $<4$ hours preoperative or warfarin $<3$ days preoperatively). Also, subjects with preexisting coagulation defects (including abnormal preoperative coagulogram [prothrombin time (PT) $>18$ seconds or partial thromboplastin time (PTT) $>50$ seconds] or platelet count $<10^{9} / \mathrm{L}$, preexisting renal dysfunction (serum creatinine $>200$ $\mathrm{mmol} / \mathrm{L}$ ), or had autologous donation of blood, were excluded from the study. Consenting subjects were randomized to receive either Colgel powder or Surgicel.

The anesthetic management and conduct of CPB were standardized. All patients were premedicated with diazepam 0.1 to $0.15 \mathrm{mg} / \mathrm{kg}$ administered orally, morphine 0.1 to $0.15 \mathrm{mg} / \mathrm{kg}$ administered intramuscularly, and scopolamine $0.01 \mathrm{mg} / \mathrm{kg}$ administered intramuscularly. Anesthesia was induced with fentanyl 3 to $5 \mu \mathrm{g} / \mathrm{kg}$ and thiopental $3 \mathrm{mg} / \mathrm{kg}$ and maintained with boli of fentanyl 100 to $200 \mu \mathrm{g}$ and midozolam $2.5 \mathrm{mg}$. Arterial hypertension was controlled by isoflurane administration. Muscle paralysis was obtained with pancuronium bromide $0.1 \mathrm{mg} / \mathrm{kg}$. The extracorporeal circuit consisted of a hollow-fiber membrane oxygenator (Baxter, Bentley, spiral oxy., hollow-fiber oxygenator). Polyvinyl chloride tubing was used throughout the circuit, except for the roller pump, which was silicone rubber. Before $\mathrm{CPB}$ was established, each patient received $3 \mathrm{mg} / \mathrm{kg}$ heparin; when the activated clotting time was shorter than 400 seconds, additional doses of heparin were administered. Heparin was reversed with protamine sulfate at a $1.3: 1$ ratio. Normothermia at $37^{\circ} \mathrm{C}$ and isothermic intermittent antegrade administration of blood potassium cardioplegic solution were used in all patients except 14 with ascending aortic aneurysm for whom femoral arterial cannulation and DHCA was used. Anastomoses and atriotomies were treated either with Colgel or with Surgicel (Ethicon, Inc, Somerville, NJ). Before closure of the median sternotomy, the remaining content of the each Colgel box (Laboratorie Interphar, Aubervilliers, France) were poured into the pericardial cavity and over the mediastinal tissues.

After the patient was transferred to the intensive care unit, continuous low-grade suction $\left(50 \mathrm{~cm}-\mathrm{H}_{2} \mathrm{O}\right)$ was applied. Complete blood count, PT, partial thromboplastin time, and platelet counts were measured before the operation and when the patients arrived at the intensive care unit. The drainage of mediastinal blood was measured hourly. The mediastinal and thoracic drains were removed when the total drainage was less than $150 \mathrm{~mL}$ over the previous 24 hours. Uniform transfusion criteria were adhered to in all patients. Blood and blood components were administered when the hematocrit level fell to less than 0.24 or the hemoglobin level fell to $7.5 \mathrm{~g} / \mathrm{L}$ in the postoperative period. Shed mediastinal blood was not transfused into any patient during this study. The indication for perioperative random donor platelets, fresh frozen plasma, was the presence of excessive active bleeding $(>200 \mathrm{~mL} / \mathrm{h})$, and a laboratory-demonstrated coagulation defect (platelet count $<100 \times 10^{9} / \mathrm{L}$, PT or PTT $>1.5 \times$ control value, or fibrinogen level $<1.0 \mathrm{~g} / \mathrm{L}$ ). With the exception of protamine to reverse the action of heparin, the nonstudy postoperative use of additional pharmacologic agents to reduce bleeding (antifibrinolytics: aprotinin, tranexamic acid, $\epsilon$-aminocaproic acid; coagulation factor enhancers: desmopressin acetate) was avoided for the 24 hours in the study. The routine immediate postoperative use of low-dose acetylsalicylic acid (300 $\mathrm{mg}$ orally per day) for the protection of ACB-graft patency, and low-dose intravenous heparin $($ PTT $<40$ ) for antithrombotic protection of valve prostheses continued, as per usual protocol, when chest tube bleeding had diminished. Full therapeutic anticoagulation (heparin and/or warfarin) for mechanical prosthetic valves was instituted after chest tube removal at 24 to 36 hours postoperatively.

We calculated for each patient the total treatment expenditure on the basis of our hospital as the sum of the costs of topical hemostatic treatment and allogeneic products transfused. The costs are following: one box of Colgel powder, $\$ 110 ; 1$ pocket of Surgicel, \$22; packed red blood cell, \$44 per unit; and fresh frozen plasma, $\$ 13$ for each unit.

Differences between the 2 groups of patients concerning hematologic and coagulative parameters were analyzed by the 2-tailed Student $t$ test, while $\chi^{2}$ test was used to analyze the differences in surgical procedures performed. The difference of data about blood loss during the first 24 postoperative hours was analyzed by 2 -way analysis of variance (ANOVA) (Colgel vs Surgicel group; time subdivided into 3-hour intervals) for repeated measures. The comparison of the blood loss during each 3-hour 
TABLE 1. Surgical procedure

\begin{tabular}{lcc}
\hline Procedure & $\begin{array}{c}\text { Colgel } \\
\text { group }\end{array}$ & $\begin{array}{c}\text { Surgicel } \\
\text { group }\end{array}$ \\
\hline Redo valve & 15 & 22 \\
Redo ACB & 3 & 1 \\
Ascending aortic aneurysm & 7 & 7 \\
$\quad \begin{array}{l}\text { repair necessary DHCA } \\
\text { Ascending aortic graft }\end{array}$ & 10 & \\
Total & 35 & 36 \\
\hline
\end{tabular}

$A C B$, Aorta-coronary bypass surgery; valve, valve replacement surgery. $P=.35 ; \chi^{2}=3.31$.

TABLE 2. Patient demographics and clinical outcome

\begin{tabular}{lccc}
\hline Patients & $\begin{array}{c}\text { Colgel } \\
\text { group }\end{array}$ & $\begin{array}{c}\text { Surgicel } \\
\text { group }\end{array}$ & $\boldsymbol{P}$ value \\
\hline $\begin{array}{l}\text { Age (y) } \\
\text { M/F }\end{array}$ & $64 \pm 6$ & $62 \pm 6$ & .20 \\
$\begin{array}{l}\text { Crossclamp time } \\
\quad \text { (min) }\end{array}$ & $30 / 5$ & $32 / 4$ & \\
$\begin{array}{l}\text { Bypass time } \\
\quad \text { (min) }\end{array}$ & $105 \pm 14$ & $95 \pm 13$ & .10 \\
$\begin{array}{l}\text { Hospital death } \\
\text { ICU stay (d) }\end{array}$ & 1 & $111 \pm 17$ & .07 \\
Hospital stay (d) & $2.49 \pm 0.87$ & $2.66 \pm 0.89$ & .42 \\
\hline
\end{tabular}

ICU, Intensive care unit.

interval between the Colgel and Surgicel groups was carried out by linear contrast, as well as the comparison of the total amount of chest drainage after the first 24 postoperative hours. The difference in total postoperative bleeding was analyzed by using the 2-tailed, unpaired Student $t$ test because the chest tubes were removed after a variable of time. Cost of treatment was evaluated by MannWhitney $U$ test.

The size of the study population had been selected based on the assumption that a total blood loss difference of at least 200 to 300 $\mathrm{mL}$ would be significant between the groups.

\section{Results}

During the study period (August 1999 and November 2001), 71 patients ( 8 women and 63 men) were included and randomized (Colgel group, $\mathrm{n}=35$; Surgicel group, $\mathrm{n}=36$ ). With respect to surgical procedures performed, the difference between the 2 groups was nonsignificant $(P=.35)$ (Table 1). The mean ( \pm SD) ages in the groups were $64 \pm$ 6 and $62 \pm 6$ years, respectively (nonsignificant) (Table 2). Preoperative and postoperative hemoglobin concentrations, hematocrit levels, platelet counts, PT, and PTT were not significantly different between the 2 groups (Tables 3 and 4). No statistically significant differences were found in the dosage of heparin or protamine administered during the operations. There were 2 in-hospital deaths ( 1 from the Colgel group, 1 from the Surgicel group). One patient in the Colgel group who underwent repeat ACB died from a
TABLE 3. Preoperative hematologic profile

\begin{tabular}{lccc}
\hline Patients & $\begin{array}{c}\text { Colgel } \\
\text { group }\end{array}$ & $\begin{array}{c}\text { Surgicel } \\
\text { group }\end{array}$ & $\boldsymbol{P}$ value \\
\hline Platelets $\left(10^{3}\right)$ & $161 \pm 28$ & $158 \pm 44$ & .80 \\
Prothrombin time (s) & $11.3 \pm 0.8$ & $13.4 \pm 1.5$ & .20 \\
Partial thromboplastin & $28.5 \pm 4.1$ & $33.2 \pm 13.2$ & .20 \\
$\quad$ time (s) & & & \\
Hemoglobin $(\mathrm{g} / \mathrm{dL})$ & $12.0 \pm 0.7$ & $11.5 \pm 1.3$ & .20 \\
Hematocrit $(\%)$ & $35 \pm 3.7$ & $35.2 \pm 3.8$ & .20 \\
Fibrinogen $(\mathrm{mg} / \mathrm{dL})$ & $218 \pm 72$ & $255 \pm 44$ & .08 \\
\hline
\end{tabular}

TABLE 4. Postoperative hematologic profile

\begin{tabular}{lccc}
\hline Patients & $\begin{array}{c}\text { Colgel } \\
\text { group }\end{array}$ & $\begin{array}{c}\text { Surgicel } \\
\text { group }\end{array}$ & $\boldsymbol{P}$ value \\
\hline Platelets $\left(10^{3}\right)$ & $109 \pm 31$ & $109 \pm 28$ & .9 \\
Prothrombin time (s) & $16 \pm 2.5$ & $15.7 \pm 1.4$ & .8 \\
Partial thromboplastin & $39.7 \pm 16$ & $42.1 \pm 34$ & .9 \\
$\quad$ time (s) & & & \\
Hemoglobin $(\mathrm{g} / \mathrm{dL})$ & $8.9 \pm 1.2$ & $8.6 \pm 1.1$ & .4 \\
Hematocrit $(\%)$ & $25.8 \pm 3.5$ & $24.5 \pm 2$ & .3 \\
Fibrinogen $(\mathrm{mg} / \mathrm{dL})$ & $208 \pm 61$ & $178 \pm 28$ & .1 \\
\hline
\end{tabular}

perioperative myocardial infarction 2 days after the operation. One patient in Surgicel group who underwent redo mitral valve replacement had a long and complicated postoperative course, including renal failure and sternal infection, and died 1 month after the operation.

Chest tube drainage in the first 24 hours was $373 \pm 143$ $\mathrm{mL}$ in the Colgel group and $571 \pm 144 \mathrm{~mL}$ in the Surgicel group $(P=.01)$. Total postoperative chest tube drainage was $423 \pm 154 \mathrm{~mL}$ (range, 280-1100 mL) in the Colgel group and $677 \pm 128 \mathrm{~mL}$ (range, 285-1350 $\mathrm{mL}$ ) in the Surgicel group $(P=.01)$. In addition, chest tube drainage was compared between the 2 groups every 3 hours after operation (Figure 1). Blood loss in the first 3 postoperative hours was significantly less in the Colgel group $(132 \pm 41$ vs $228 \pm 57 \mathrm{~mL}, P<.001)$. In the following 3-hour interval this significant difference persisted $(67 \pm 24$ vs $121 \pm 49$ $\mathrm{mL}, P<.001)$. In the remaining 3-hour intervals, the blood loss in the Colgel group was lower compared with the Surgicel group, but the differences did not reach a significant level. In the Colgel group $(n=35), 6$ patients received 28 units of packed red blood cells; in the Surgicel group, 20 patients received 120 units of packed red blood cells. In order to improve blood coagulation, 8 patients of the Surgicel group received a total of 46 units of fresh frozen plasma, while only 2 patients of the Colgel group received 8 units of fresh frozen plasma. The number of packed red blood cells as well as the total number of blood products required is just nonsignificant in the 2 -tailed test $(P<.07)$, while the difference in the 1 -tailed test is significant $(P<$ $.03)$. 


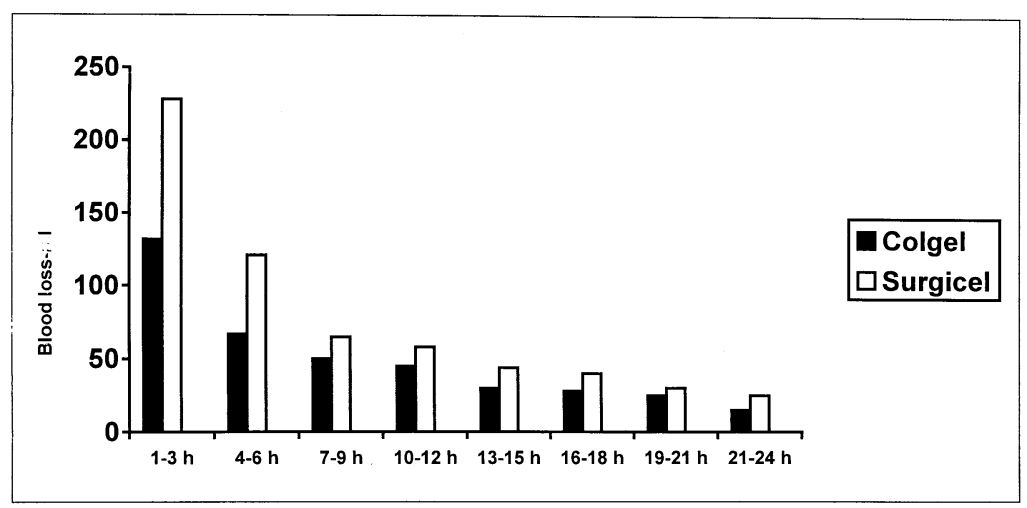

Figure 1. Postoperative blood loss measured every 3 hours.

The cost of topical hemostatic agent treatment and the transfusion requirement were significantly lower in the Colgel group compared with the Surgicel group $(\$ 152 \pm \$ 22$ vs $\$ 202 \pm \$ 29$, respectively, $P<.001)$.

\section{Conclusions}

The high risk of bleeding in high-risk procedures necessitates the use of drugs to reduce postoperative bleeding and transfusion requirements. The study of Magovern and colleagues ${ }^{6}$ shows that the need for blood transfusion can be readily predicted from preoperative patient-related variables, ie, emergency and unstable preoperative patient status, factors associated with low preoperative red cell volume, and comorbid conditions and diseases. Although it is known that platelet activation and subsequent dysfunction increase with the duration of $\mathrm{CPB}$, and procedures requiring long CPB times increase the risk of bleeding, in that study surgical factors such as the length of CPB longer than 105 minutes and redo sternotomy were only minor contributors. ${ }^{6}$ Also in our study, the duration of CPB was nonsignificant between the groups $(105 \pm 11 \mathrm{~min}$ and $111 \pm 17 \mathrm{~min}$ in Colgel and Surgicel group, respectively), and we do not think it influenced our results. The aim of this study was to determine if microfibrillar Colgel powder was efficacious in reducing blood loss and transfusion requirements compared with oxidized cellulose (Surgicel) in cardiac operations associated with high risk of bleeding.

Microfibrillar collagen was initially described in $1969 .{ }^{7}$ It is a water-insoluble acid salt of bovine collagen prepared by a process that conserves the normal helical configuration of the tropocollagen molecule and most of the lateral bonding forces between these molecules. Because of its potential multiplicity of form, it was thought that it would be ideal as a vascular prosthesis. It was only when intense thrombogenic activity in these grafts was noted ${ }^{8}$ that its potential use as a hemostatic agent was considered. ${ }^{8,9}$ Topically used microfibrillar collagen adheres to the bleeding site and provides some tamponade hemostatic effect and initiates platelet activation and aggregation. It also reinforces the fibrin clot that formed. ${ }^{8,9}$

Since that time, other reports indicate that it is probably effective as a local hemostatic agent. ${ }^{10,11}$ The bleeding surface is first sponged dry, then, with quick short bursts by squeezing the powder box, the hemostatic agent is blown onto the surfaces prone to bleeding.

Surgicel (oxidized cellulose) provides a lattice for natural clot formation. ${ }^{12}$

In the present study, there was a significant difference between the Colgel and the Surgicel groups in terms of intraoperative blood loss and postoperative drainage volumes. (chest tube drainage in the first 24 hours was $373 \pm$ $143 \mathrm{~mL}$ in the Colgel group and $571 \pm 144 \mathrm{~mL}$ in the Surgicel group) While 120 units of packed red blood cells were used for the Surgicel group, only 28 units were used for the Colgel group. The reduction in blood loss was significant in the initial 3 postoperative hours. It may be due to the early hemostatic effect of microfibrillar collagen.

In a previous report it was postulated that $27 \%$ of patients receive unnecessary blood transfusions. ${ }^{13} \mathrm{~A}$ recent publication has revealed the high costs of allogeneic blood transfusions. ${ }^{14}$ This includes the cost of collection, production, distribution, and delivery. The cost of bleeding includes not only the cost of drug/transfusion therapy, but also the materials and manpower of reoperations, prolonged intensive care, and the treatment of complications of largevolume blood-product transfusions. These costs are enormous in comparison to the cost of the drug therapy. ${ }^{13}$ At our institution, 1 box of Colgel powder is $\$ 110$ and is quite reasonable when the reduction in blood loss provided by this agent is considered.

In conclusion, the easy application, low cost, and significant blood-loss reduction effect of microfibrillar collagen powder render this agent attractive for cardiac operations associated with high risk of bleeding. 


\section{References}

1. Karski JM, Teasdale SJ, Norman P, Carroll J, Van Kessel K, Wong P, et al. Prevention of bleeding after cardiopulmonary bypass with highdose tranexamic acid. Double-blind, randomized clinical trial. $J$ Thorac Cardiovasc Surg. 1995;110:835-42.

2. Charles WH, Steven WM, Brian RK, Hoang ST, Matthew MP, Frank AC, et al. BioGlue surgical adhesive for thoracic repair during coagulopathy: efficacy and histopathology. Ann Thorac Surg. 2001;71:1609-12.

3. Tatar H, Sertac C, Ufuk D, Ertugrul O, Hikmet S, Omer O, et al. Topical use of aprotinin in open heart operations. Ann Thorac Surg. 1993;55:659-61.

4. O’Regan DJ, Giannopoulus N, Mediratta N, Kendall SWH, Forni A, Pillai R, et al. Topical aprotinin in cardiac operations. Ann Thorac Surg. 1994;58:778-81.

5. Spotnitz WD, Dalton MS, Baker JW, Nolan SP. Reduction of perioperative hemorrhage by anterior mediastinal spray application of fibrin glue during cardiac operations. Ann Thorac Surg. 1987;44:529-31.

6. Magovern JA, Sakert T, Benckart DH, Burkholder JA, Liebler GA, Magovern GJ, Magovern GJ Jr. A model for predicting transfusion after coronary artery bypass grafting. Ann Thorac Surg. 1996;61:27-32.
7. Battista OA, Erdi NZ, Ferraro CF, Karasinsky FJ. Novel microcrystals of polmers, Part II. J Appl Polymer Sci. 1967;11:481.

8. Hait MR, Battista OA, Stark RB, McCord CW. Microcrystalline collagen as a biologic dressing, vascular prothesis, and hemostatic agent. Surg Forum. 1969;20:51.

9. Hait MR. Microcrystalline collagen: a new hemostatic agent. Am $J$ Surg. 1970;120:330.

10. Hait MR. Comparative evaluation of Avitene microcrystalline collagen hemostat in experimental animal wounds. Am J Surg. 1973;125: 284.

11. Wilkonson TS, Tenery JH, Zufi D. The skin graft donor site as a model for evaluation of hemostatic agents. Plast Reconstruct Surg. 1973;51: 541.

12. Wagner WR, Pachence JM, Ristich J, Johnson PC. Comparative in vitro analysis of topical hemostatic agents. J Surg Res. 1996;66:100-8.

13. Harmon DE. Cost/benefit analysis of pharmacologic hemostasis. Ann Thorac Surg. 1996;61:S21-5.

14. Tretiak R, Laupacis A, Riviere M, McKerracher K, Souetre E. Canadian cost of transfusion study group. Cost of allogeneic and autologous blood transfusion in Canada. Can Med Assoc J. 1996;154:1501-8. 